\title{
ANALISIS KINERJA MANAJEMEN BERDASARKAN BALANCED SCORECARD
}

\author{
Jumingan \\ STIE A tma Bhakti Surakarta
}

\begin{abstract}
The purpose of the research was to help CV. Angkasa manager in measuring business growth level and increasing capability and also commitment personal, They were expected could increase employee productivity and make production time more efficient so that able to increase service quality to customer.

The research is case study was applied on CV. Angkasa, Using descriptive methodology. Variables in this research using forth perspective in Balanced Scorecard are financial perspective, customer perspective, internal business process perspective, learning and growth perspective .

The results showed (1) financial on CV. Angkasa was good, (2) most of customer's were satisfied on its product's even though there were complaint of delay product's distribution (3) inefficiency production time was reason of delay product's distribution occurred (4) lower employee ethos was caused by lower company attention which had on impact to relationship between employee and manager that will affect employee productivity.
\end{abstract}

Key words: balanced scorecard, Financial Perspective, Customer Perspective, (Internal) Business Process, Learning and Growth Perspective.

\section{ABSTRAK}

Penelitian ini bertujuan untuk membantu pihak manajemen dalam mengukur tingkat pertumbuhan bisnisnya serta nantinya CV. Amanah dapat meningkatkan kapabilitas dan komitmen personel pada akhirnya dapat meningkatkan produktivitas karyawan dan mengefisienkan waktu produksi sehingga mampu meningkatkan mutu pelayanan kapada pelanggan.

Penelitian ini merupakan studi kasus pada CV. Amanah, dengan menggunakan metode deskriptif. Variabel yang digunakan dalam penelitian ini adalah keempat perspectif dalam Balance Scorecard yaitu perspektif keuangan, perspektif pelanggan, perspektif proses bisnis internal dan persepktif pembelajaran dan pertumbuhan.

Berdasarkan hasil analisis data menunjukkan: (1) kondisi keuangan CV. Amanah dapat dikategorikan baik; (2) sebagian besar pelanggan merasa puas terhadap produk yang dihasilkan meskipun, sebagian besar pelanggan masih mengeluhkan tentang keterlambatan dalam pendistribusian produk; (3) tidak efisiennya waktu yang digunakan dalam proses produksi menjadi salah satu penyebab terjadinya keterlambatan dalam pendistribusian produk; (4) masih 
rendahnya etos kerja karyawan CV. Amanah disebabkan perusahaan kurang memperhatikan kepuasan karyawan yang berdampak pada hubungan kerjasama antara manajer dan karyawan yang dapat mempengaruhi tingkat produktivitas karyawan.

Kata kunci: balanced scorecard, perspektif keuangan, perspektif pelanggan, perspektif proses bisnis internal, perspektif pertumbuhan dan pembelajaran.

Pengukuran kinerja yang hanya mengacu pada aspek finansial saja, dirasa sudah tidak lagi memadai, dan pada kenyataannya mengandung banyak kelemahan salah satunya sulit untuk mengukur hal- hal yang mempengaruhi kinerja perusahaan dari segi non keuangan, misalnya : kepuasan customer terhadap layanan jasa perusahaan, kedekatan hubungan kemitraan antara pemasok dengan customer, pengembangan perusahaan dan pengembangan karyawannya, karena kinerja keuangan yang memuaskan saat ini sangat mungkin pula telah mengorbankan kepentingankepentingan jangka panjang perusahaan, dengan demikian kinerja keuangan dinilai tidak sepenuhnya mampu bercerita banyak mengenai masa lalu perusahaaan termasuk keandalannya dalam menuntun manajemen ke arah perbaikan yang berkelanjutan (Mulyadi, 2001). Selain itu, ukuran finansial juga tidak mampu untuk menuntun dan mengevaluasi perjalanan perusahaan melalui lingkungan yang kompetitif.

Guna mengatasi kebiasaan yang muncul dari metode-metode pengukuran yang hanya mengukur kinerja perusahaan hanya dari satu aspek saja maka lahirlah alternatif yang lebih baik dalam pengukuran kinerja perusahaan dengan mempertimbangkan empat perspektif : Perspektif Keuangan, Customer, Proses Internal Bisnis serta Proses Pembelajaran dan Pertumbuhan (Kaplan dan Norton, 1996:7). Gagasan untuk menyeimbangkan pengukuran aspek keuangan dan non keuangan melahirkan apa yang dinamakan Balanced Scorecard. Balanced Scorecard memberikan suatu cara untuk mengkomunikasikan strategi suatu perusahaan pada manajer-manajer diseluruh organisasi (Tunggal, 2001:1).

\section{TELAAH PUSTAKA}

\section{Balanced Scorecard}

Balanced Scorecard mencakup berbagai aktivitas penciptaan nilai yang dihasilkan oleh para pertisipan perusahaan yang memiliki kemampuan dan motivasi tinggi, sementara tetap memperhatikan kinerja jangka pendek, yaitu melalui perspektif finansial. Pendekatan Balanced Scorecard mampu mengatasi berbagai kelemahan yang ada pada pengukuran kinerja tradisional. Balanced Scorecard merupakan sistem pengukuran kinerja yang tetap mempertahankan tolok ukur keuangan sebagai indikator tindakan manajemen di masa lalu dengan menambahkan ukuranukuran dalam perspektif customer, proses internal bisnis, serta perspektif pembelajaran dan pertumbuhan sebagai pemicu kinerja di masa depan (Anthony dan Govindarajan, 1998 : 54).

Selama ini yang menjadi permasalahan pada CV Amanah adalah Sistem pencatatan laporan keuangan CV. Angkasa yang belum sistematis dan belum pernah melakukan pegukuran kinerja keuangan selain itu halhal yang mempengaruhi kinerja perusahaan dari segi non keuangan terabaikan. Berdasarkan data yang ada, dilihat dari perspektif customer, CV.Amanah tidak bisa 
mempertahankan

keseluruhan

pelanggannya untuk tetap menggunakan produk perusahaan, dan pihak manajemen sering menerima keluhan dari pelanggan mengenai keterlambatan pendistribusian produk. Keterlambatan pendistribusian produk itu disebabkan karena produk tidak bias jadi tepat waktu sesuai dengan jadwal yang sudah direncanakan. Untuk perspektif pembelajaran dan pertumbuhan, masih rendahnya etos kerja karyawan.

Dengan diterapkannya

Balanced Scorecard diharapkan nantinya CV. Amanah mampu mengukur tingkat pertumbuhan bisnisnya dan dapat menggunakan sistem pencatatan laporan keuangan dengan seperangkat Teknologi Informasi agar mempercepat keakuratan laporan keuangan secara sistematis, terukur. Selain itu diharapkan CV. Amanah Surakarta dapat meningkatkan kapabilitas dan komitmen personel, sehingga nantinya dapat mempersingkat waktu proses produksi, yang nantinya mampu mempercepat produk sampai ketangan pelanggan dan terarah, sehingga mampu meningkatkan mutu pelayanan kepada pelanggan.

Dalam penelitian ini, peneliti mengevaluasi kinerja CV. Amanah Surakarta yang ditinjau dari empat perspektif yang ada pada Balanced Scorecard, yaitu perspektif keuangan, perspektif pelanggan, perspektif proses bisnis internal, dan perspektif pembelajaran dan pertumbuhan.

\section{METODE PENELITIAN}

Penelitian ini merupakan studi kasus pada CV. Amanah surakarta. Dalam penelitian ini peneliti menggunakan metode penelitian deskriptif. Sumber data diperoleh langsung dari objek penelitian. Data tersebut meliputi data lokasi perusahaan, struktur organisasi, bidang operasi, proses produksi, sejarah perusahaan, laporan keuangan tahunan perusahaan meliputi neraca dan laba rugi tahun 2011-2013, jumlah pelanggan, jumlah karyawan, dan pembagian kuisioner untuk mengukur kepuasan palanggan dan kepuasan karyawan.

Dalam penelitian ini populasinya adalah aktivitas perusahaan CV. Amanah Surakarta. Cara pengambilan sampel dengan menggunakan teknik random proportional sampling, yaitu cara pengambilan sampel dari tiap-tiap sub populasi dengan memperhitungkan besar kecilnya sub populasi. Untuk mengukur tingkat kepuasan pelanggan/customer satisfaction, Sampel populasi yang diambil untuk pelanggan yang berada di Boyolali dan Karanganyar. Jumlah sampel yang diambil sebanyak 78 pelanggan, Untuk mengukur tingkat kepuasan karyawan,Populasi diambil pada keseluruhan karyawan CV. Amanah Surakarta sebanyak 25 karyawan.

Variabel dalam penelitian ini adalah keempat perspektif yang ada pada Balanced Scorecard. Pada perspektif keuangan yang menjadi tolak ukur adalah ROI, Net Profit Margin, dan pertumbuhan pendapatan. Pada perspektif pelanggan yang menjadi tolak ukur adalah market share, tingkat penambahan jumlah pelanggan, retensi pelanggan, dan kepuasan pelanggan. Untuk perspektif proses bisnis internal yang menjadi tolak ukur adalah tingkat efisiensi waktu, dan jumlah produk yang berhasil dikembangkan. Sedangkan pada perspektif pembelajaran dan pertumbuhan adalah tingkat perputaran karyawan, produktivitas karyawan, dan kepuasan karyawan.

\section{HASI L DAN PEMBAHASAN}

\section{Teknik Analisis Data}

Dalam membahas permasalahan ini, prosedur yang dilakukan dalam pengukuran kinerja dengan konsep Balanced Scorecard, adalah:

1. Merumuskan Balanced Scorecard dengan langkah sebagai berikut:

a. Klarifikasi strategi yang dijalankan perusahaan 
b. Menjabarkan tujuan yang ingin dicapai oleh masing-masing strategi dalam empat perspektif Balanced Scorecard.

c. Menentukan tolak ukur untuk tujuan strategis.

2. Mengukur kinerja CV. Amanah Surakarta dengan konsep Balanced Scorecard berdasarkan empat perspektif.

\section{Hasil dan analisis data}

Berikut ini ini merupakan pengukuran kinerja pada CV. Amanah Surakarta berdasar keempat perspetif Balanced Scorecard

\section{Perspektif finansial}

\section{Tabel 1.Tabel Kinerja}

\begin{tabular}{crrrc}
\hline Ukuran & $\mathbf{2 0 1 1}$ & $\mathbf{2 0 1 2}$ & $\mathbf{2 0 1 3}$ & Rata-rata \\
\hline ROI & $7,23 \%$ & $6,93 \%$ & $7,37 \%$ & $7,17 \%$ \\
\hline Profit margun $15,53 \%$ & $14,21 \%$ & $14,99 \%$ & $14,91 \%$ \\
\hline $\begin{array}{l}\text { Pertumbuhan } \\
\text { pendapatan }\end{array}$ & $11,51 \%$ & $7,71 \%$ & $15,15 \%$ & $11,46 \%$ \\
\hline
\end{tabular}

Sumber : data internal perusahaan

\section{a. ROI}

Ratio ini menunjukkan apakah laba yang dihasilkan sudah cukup jika dibandingkan dengan aktiva yang diinvestasikan. Dari tabel di atas, selama tiga tahun tingkat ROI yang diperoleh perusahaan tidak tetap. Pada tahun 2011, menghasilkan ROI sebesar $7,23 \%$. Pada tahun 2012, mengalami sedikit penurunan menjadi 6,93\%. Kemudian pada tahun 2013, mengalami peningkatan sebesar $7,37 \%$. Meskipun sempat mengalami penurunan di tahun 2012, tapi kenaikan di tahun 2013 memperlihatkan pertumbuhan bahwa ROI dipengaruhi oleh penjualan, penyusutan aktiva dan total aktiva.

\section{b. Net Profit Margin}

Net Profit Margin adalah ukuran profitabilitas perusahaan dari penjualan setelah memperhitungkan semua biaya dan pajak penghasilan. Dari tabel di atas, untuk tahun 2011 perusahaan mampu menghasilkan net profit margin sebesar $15,53 \%$. Sedang pada tahun 2012 mengalami penurunan menjadi $14,21 \%$. Di tahun 2013 profit margin mengalami kenaikan lagi sebesar $14,99 \%$. Net Profit Margin sebesar $14,49 \%$ dapat diartikan bahwa setiap rupiah penjualan menghasilkan keuntungan neto sebesar Rp. 0,1499. Besarnya net profit margin di tahun 2012 dan 2013 menunjukkan nilai yang lebih rendah jika dibandingkan dengan tahun 2011. Hal ini bisa disebabkan karena adanya kenaikan pada biaya produksi dan biaya operasionalnya. Tetapi kenaikan itu tidak diikuti dengan kenaikan harga jualnya, 
akibatnya net profit marginnya mengalami penurunan. Dengan kata lain, manajeman kurang bisa memperahankan biaya dan beban secara relatif dengan penjualan. Semakin besar nilai rasio yang didapat, maka dapat dikatakan bahwa perusahaan relatif lebih efisien. Besarnya profit margin akan berpengaruh terhadap tingkat pengembalian investasi atau ROI.

\section{Pertumbuhan pendapatan}

Pertumbuhan

merupakan

pendapatan bersih dari

tahun. pendapatan, menunjukkan keberhasilan perusahaan dalam menjalankan strateginya. Dari data diatas, pertumbuhan pendapatan ditahun 2013 mengalami kenaikan pendapatan yang cukup besar dibanding tahun-tahun sebelumnya, yaitu sebesar $15,15 \%$. Kenaikan ini disebabkan karena jumlah pelanggan yang semakin bertambah. Bertambahnya jumlah pelanggan menyebabkan jumlah yang harus diproduksi bertambah pula, sehingga pendapatan yang diterima juga mengalami kenaikan. Dengan semakin tingginya tingkat pertumbuhan pendapatan suatu perusahaan, maka semakin baik pula perusahaan mampu memenuhi kesejahteraan karyawannya.

\section{Perspektif Pelanggan}

\section{a. Market Share}

Market Share atau disebut juga dengan penguasaan pasar yang menggambarkan seberapa besar penguasaan segmen pasar produk, diukur dalam jumlah pelanggan, rupiah yang dibelanjakan, atau volume unit yang dijual. Dalam penelitian ini, tingkat pangsa pasar diukur untuk penguasaan segmen produk majalah TK untuk masing-masing daerah.

Tabel. 2(a) Penguasaan pangsa pasar untuk produk majalah TK

\begin{tabular}{lcccc}
\hline \multicolumn{1}{c}{ Daerah } & $\mathbf{2 0 1 1}$ & $\mathbf{2 0 1 2}$ & $\mathbf{2 0 1 3}$ & Rata-rata \\
\hline Bojonegoro & $15,78 \%$ & $18,42 \%$ & $20 \%$ & $18.06 \%$ \\
\hline Pasuruan & $14,47 \%$ & $14,8 \%$ & $15,62 \%$ & $14,96 \%$ \\
\hline Sitobondo & $23,33 \%$ & $23,8 \%$ & $24,76 \%$ & $23,96 \%$ \\
\hline Bondowoso & $25 \%$ & $26,7 \%$ & $30 \%$ & $27,23 \%$ \\
\hline Cilacap & - & - & $4,14 \%$ & $4,14 \%$ \\
\hline
\end{tabular}

Sumber : data internal perusahaan

Dari tabel 2(a) terlihat bahwa untuk penguasaan pangsa pasar menunjukkan kenaikan yang cukup bagus. Meskipun kenaikannya sedikit, tetapi hal ini menunjukkan keberhasilan bagian pemasaran dalam menjalankan tugasnya. Terlihat di tahun 2013, berhasil memasarkan produknya di Cilacap.

Dalam memasarkan produknya,
CV. Amanah tidak menjadi pemain tunggal. CV. Amanah harus bersaing dengan kompetiter lainnya. Ada tujuh percetakan yang bergerak dibidang dan wilayah pemasaran yang sama. Intan Pariwara-Klaten, Prima IImuKlaten, Citra-Surabaya, Putra Nugraha, Airlangga, Asri Mandiri, dan NasonoJember. 
b. Penambahan jumlah (customer acquisition)

Merupakan jumlah pelanggan baru yang datang untuk memberikan kepercayaan kepada perusahaan untuk memberikan jasanya. Semakin besar angka customer acquition menunjukkan bahwa kinerja perusahaan semakin baik.

Tabel 2(b) Penambahan jumlah pelanggan (customer acquition)

\begin{tabular}{ccccc}
\hline No & Tahun & $\begin{array}{c}\text { Jml } \\
\text { pelanggan } \\
\text { awal tahun }\end{array}$ & $\begin{array}{c}\text { Pelanggan } \\
\text { masuk }\end{array}$ & $\begin{array}{c}\text { Penambahan } \\
\text { jml pelanggan } \\
\mathbf{( \% )}\end{array}$ \\
\hline 1 & 2011 & 260 & 15 & $5,7 \%$ \\
\hline 2 & 2012 & 272 & 20 & $7,35 \%$ \\
\hline 3 & 2013 & 290 & 52 & $17,93 \%$ \\
\hline \multicolumn{2}{c}{ Rata-rata } & & 29 & $10,32 \%$ \\
\hline
\end{tabular}

Sumber : data internal perusahaan

Berdasarkan tabel 2(b), dapat dilihat bahwa tiap tahunnya ada penambahan jumlah pelanggan yang masuk ke CV. Amanah. Hal ini menunjukkan bahwa produk-produk CV. Amanah sudah mulai diminati oleh banyak sekolah, sehingga makin banyak pelanggan (sekolah) yang menggunakan produk (buku) dari CV. Amanah

\section{c. Retensi Pelanggan (customer retention)}

Merupakan jumlah pelanggan lama yang masih tetap loyal kepada perusahaan, yang ditunjukkan dengan kesediannya untuk datang kembali mempercayai perusahaan untuk memberikan jasanya. Semakin besar customer retention menunjukkan kinerja perusahaan semakin baik.

Tabel. 2(c) Retensi Pelanggan (customer retention)

\begin{tabular}{ccccc}
\hline Tahun & $\begin{array}{c}\text { Jml } \\
\text { pelanggan } \\
\text { awal tahun }\end{array}$ & $\begin{array}{c}\text { Pelangga } \\
\text { n masuk }\end{array}$ & $\begin{array}{c}\text { Pelangga } \\
\text { n keluar }\end{array}$ & $\begin{array}{c}\text { Retensi } \\
\text { pelangga } \\
\mathbf{n}\end{array}$ \\
\hline 2011 & 260 & 15 & 3 & $98,8 \%$ \\
\hline 2012 & 272 & 20 & 2 & $99,2 \%$ \\
\hline 2013 & 290 & 52 & 1 & $99,65 \%$ \\
\hline \multicolumn{2}{c}{ Rata-rata } & & & $99,21 \%$ \\
\hline
\end{tabular}

Sumber: data internal perusahaan

Berdasarkan tabel 2(c), dari tahun 2011 sampai dengan 2013 retensi pelanggan yang menunjukkan loyalitas pelanggan lama sangat baik. Hal ini dapat dilihat dari jumlah pelanggan yang keluar di tahun 2008 tidak ada sama sekali.

\section{d. Kepuasan Pelanggan}

Semakin tinggi kepuasaan pelanggan menunjukkan kinerja perusahaan semakin baik. Kepuasan pelanggan didukung oleh kualitas pelayanan yang dilakukan oleh perusahaan. Untuk menilai apakah kepuasan pelanggan termasuk dalam kategori baik, perusahaan 
menetapkan standar sebanyak $55 \%$ untuk masing-masing faktor. Faktorfaktor yang dimaksud meliputi: pelanggan merasa puas terhadap produk, harga dan pelayanan pendistribusian produk.

Hasil dari penelitian didapat, sebanyak $75 \%$ pelanggan merasa puas terhadap produk yang dihasilkan, $58,75 \%$ pelanggan merasa puas terhadap harga yang ditawarkan. Ini berarti bahwa tingkat kepuasan pelanggan terhadap produk dan harga yang ditawarkan sudah baik. Sedangkan untuk pendistribusian produk, sebanyak $62,5 \%$ pelanggan merasa kurang puas terhadap pelayanan yang diberikan. Dari sini kita dapat mengetahui apa yang menjadi penyebab adanya complain dari pelanggan. Ternyata perusahaan hanya berfokus terhadap kulitas produk yang ditawarkan tanpa merperhatikan kulitas pelayanan yang seharusnya juga diperhatikan.

Secara keseluruhan jumlah pelanggan yang merasa puas terhadap kinerja perusahaan sebanyak $56 \%$ dan $44 \%$ menyatakan kurang puas. Dari hasil ini dapat disimpulkan bahwa tingkat kepuasan karyawan CV. Amanah sudah baik.

\section{Perspektif Proses Bisnis Internal}

a. Jumlah Produk Baru yang Berhasil Dikembangkan

Tolok ukur ini menggambarkan tingkat keberhasilan perusahaan dalam melakukan proses inovasi.

Tabel 3(a) Jumlah produk yang berhasil dikembangkan

\begin{tabular}{lrrr}
\hline \multicolumn{1}{c}{ Ukuran } & $\mathbf{2 0 1 1}$ & $\mathbf{2 0 1 2}$ & $\mathbf{2 0 1 3}$ \\
\hline $\begin{array}{l}\text { Jumlah produk yang } \\
\text { berhasil } \\
\text { dikembangkan }\end{array}$ & 1 & 1 & 0 \\
\hline
\end{tabular}

Sumber : data internal perusahaan

Ternyata dalam jangka waktu tiga tahun, perusahaan tidak mengembangkan produk baru. Produk terakhir yang berhasil dikembangkan oleh PAI (Pendidikan Agama Islam). Tetapi produksinya hanya enam bulan sekali, sehingga laba yang dihasilkan kurang memuaskan.

\section{b. Mengukur Tingkat Efisiensi}

Tingkat efisiensi diukur dengan MCE (Manufacturing Cycle Efficiency) Jika nilai MCE semakin mendekati angka satu, berarti akan semakin baik tingkat efisiensinya.

Tabel. 3(b) Manufacturing Cycle Effectiveness (MCE)

\section{Ukuran 201120122013 Rata-rata}

\begin{tabular}{lllll}
\hline MCE & 0,091 & 0,07 & 0,1 & 0,087
\end{tabular}

\section{Sumber: Data internal perusahaan}

Dari label 3(b) diketahui untuk tahun 2011, MCE bermial 0,091. Di tahun 2012 perusahaan mencapai tingkat efisiensi 0,07 dan ditahun 2013, MCE bernilai 0,1. Angka-angka tersebut masih jauh dari angka satu, sehingga dapat dikatakan bahwa perusahaan masih banyak menggunakan aktivitas 
Jurnal Bisnis \& M anajemen

Vol. 15, N 0. 1, $2015: 45$ - 56

yang tidak bernilai tambah.

Perputaran karyawan diukur dengan persentase keluarnya

\section{Perspektif Pembelajaran, dan} Pertumbuhan

a. Perputaran Karyawan / tumover

pekerja. Semakin kecil

perputaran karyawan, berarti kinerja perusahaan semakin baik.

Tabel 4(a) Perputaran Karyawan

\begin{tabular}{ccccc}
\hline Tahun & $\begin{array}{c}\text { Karyawan } \\
\text { keluar }\end{array}$ & $\begin{array}{c}\text { Karyawan } \\
\text { masuk }\end{array}$ & $\begin{array}{c}\text { Jumlah } \\
\text { Perputaran } \\
\text { karyawan }\end{array}$ \\
\hline 2011 & 2 & 3 & 24 & $8,3 \%$ \\
\hline 2012 & 1 & 2 & 25 & $4 \%$ \\
\hline 2013 & 1 & 1 & 25 & $4 \%$ \\
\hline \multicolumn{2}{c}{ Rata-rata } & & & $5,4 \%$
\end{tabular}

Sumber: data internal perusahaan

Dari tabel 4(a), dapat dilihat kemampuan perusahaan dalam mempertahankan karyawannya semakin lama semakin baik. Hal itu ditunjukkan dengan nilai persentase yang semakin lama semakin menurun. Ini berarti, perusahaan telah memperhatikan kesejahteraan karyawannya. Terbukti dari tidak adanya karyawan yang keluar dari perusahaan.

\section{b. Produktivitas Karyawan}

Tabel 4(b). Produktivitas karyawan

\begin{tabular}{lllll}
\hline ukuran & $\mathbf{2 0 1 1}$ & $\mathbf{2 0 1 2}$ & $\mathbf{2 0 1 3}$ & Rata-rata \\
\hline $\begin{array}{l}\text { Produktivitas } \\
\text { karyawan }\end{array}$ & 8.374 .914 & 8.659 .926 & 9.972 .059 & 9.002 .300 \\
\hline
\end{tabular}

Sumber: Data primer diolah

Tolok ukur ini menunjukkan suatu ukuran hasil dampak keseluruhan usaha peningkatan moral dan keahlian pekerja, inovasi, proses internal, dan kepuasan pelanggan. Ukuran produktivitas pekerja antara lain adalah pendapatan per pekerja. Semakin efektifnya pekerja dalam lebih banyak menjual produk dengan nilai tambah yang meningkat, pendapatan per pekerja juga meningkat.

Tabel 4(b) menunjukan produktivitas seluruh karyawan yang terus meningkat dari tahun ke tahun. Kenaikan ini didukung dengan peralatan yang memadai, seperti mesin baru yang memiliki kecepatan cetak hampir tiga kali lipatnya dari mesin sebelumnya. Selain itu ketrampilan karyawan dalam mengoperasikan mesin ini sudah mengalami peningkatan yang cepat.

\section{c. Kepuasan Karyawan}

Kepuasan kerja berhubungan erat dengan sikap karyawan terhadap pekerjaannya sendiri, situasi kerja serta kerjasama antara pimpinan dan bawahan. Dan yang tidak kalah pentingnya adalah besarnya tingkat upah/gaji yang diterima. Puas atau 
tidaknya karyawan terhadap perilaku pimpinannya akan sangat berpengaruh terhadap kinerja bawahan. Pengaruh tersebut bisa positif atau negatif, tergantung pada situasi dan kondisi perusahaan.

Untuk mengukur baik atau buruknya tingkat kepuasan karyawan, perusahaan menetapkan standar sebesar $60 \%$ karyawan menyatakan puas terhadap tingkat penggajian/pengupahan. Dari hasil penelitian didapatkan, sebanyak $68 \%$ karyawan menyatakan puas terhadap tingkat penggajian dan pegupahan. Ini berarti tingkat kepuasan karyawan sudah baik.

Untuk mengetahui penyebab rendahnya etos kerja karyawan di CV. Amanah, peneliti tidak hanya mengukur tingkat kepuasan karyawan terhadap gaji/upah tetapi juga mengukur tingkat kepuasan yang lain. Seperti kepuasan terhadap peraturanperaturan, kepuasan terhadap penghargaan yang diberikan pimpinan, dan kepuasan terhadap pujian yang diberikan pimpinan.

Dari hasil penelitian, dapat diketahui bahwa sebanyak $64 \%$ karyawan menyatakan kurang puas terhadap penghargaan yang diberikan perusahaan. Selain itu sebanyak $68 \%$ karyawan merasa kurang puas terhadap peraturan yang diterapkan di perusahaan. Tidak adanya penghargaan dan pujian yang diberikan pimpinan kepada bawahan serta peraturan yang terlalu ketat menyebabkan tidak adanya semangat dan motivasi dalam diri karyawan. Sehingga dapat mempengaruhi etos kerja dari karyawan itu sendiri.

Secara keseluruhan jumlah karyawan yang merasa puas terhadap kinerja perusahaan sebanyak $68 \%$ dan $32 \%$ menyatakan kurang puas. Dari hasil ini dapat disimpulkan bahwa tingkat kepuasan karyawan CV. Amanah sudah baik.

\section{Menentukan Nilai Tambah Yang didapatkan dengan Penerapan Balanced scorecard}

Keempat perspektif dalam Balanced Scorecard mempunyai keterkaitan satu sama lain dan merupakan satu kesatuan yang tidak dapat terpisah-pisah. Hal ini yang menjadi nilai tambah dengan penerapan Balanced Scorecard. Keseimbangan antar Scorecard dari masing-masing perspektif dapat menentukan peningkatan kinerja perusahaan. Peningkatan kinerja perspektif pertumbuhan dan pembelajaran akan mendorong peningkatan kinerja perspektif proses bisnis internal dan perspektif pelanggan yang akan mendorong kinerja finansial perusahaan secara keseluruhan sehingga terjadi peningkatan kinerja perusahaan.

Perspektif pertumbuhan dan pembelajaran mempunyai hubungan/keterkaitan dengan perspektif proses bisnis internal. Hal ini dapat kita lihat dari tingkat turnover tenaga kerja yang tinggi menyebabkan perusahaan tidak dapat melakukan aktivitas produksinya secara maksimal, artinya terjadi ketidakefektivan penggunaan waktu kerja oleh perusahaan. Ketidakpuasan karyawan akan mempengaruhi kinerja, loyalitas serta dedikasi yang tinggi pada pekerjaan.

Semakin tinggi tingkat kepuasan karyawan, maka motivasi karyawan untuk bekerja dengan lebih baik akan meningkat pula, sehingga akan mempengaruhi efiktivitas waktu kerja (dalam hal ini pemanfaatan mesin-mesin penunjang proses produksi secara maksimal). Dengan pemanfaatan proses produksi secara maksimal akan mempercepat produksi selesai tepat waktu, sehingga produk dapat cepat sampai ketangan pelanggan. Pelayanan yang tepat waktu akan meningkatkan kepuasan pelanggan dan meningkatkan loyalitas pelanggan pada 
perusahaan serta dimungkinkan akan meningkatkan jumlah pelanggan. Peningkatan jumlah pelanggan berdampak pada peningkatan pendapatan perusahaan yang akan meningkatkan profit margin. Hal ini menunjukkan hubungan/keterikatan antara perspektif pertumbuhan dan pembelajaran, perspektif proses bisnis internal, perspektif pelanggan dan perspektif keuangan.

Nilai tambah yang didapatkan perusahaan dengan penerapan Balanced Scorecard yaitu, perusahaan akan mendapatkan informasi yang lengkap dan komprehensif berkaitan dengan kinerja organisasi. Informasi yang didapatkan perusahaan tidak hanya dari sisi keuangan saja, melainkan dari sisi pelanggan, proses bisnis internal serta pertumbuhan dan pembelajaran.

\section{SIM PULAN}

\section{Simpulan}

Dari kasus yang ada pada CV. Amanah, maka dapat diambil kesimpulan sebagai berikut:

1. Perlu diadakannya sistem pencatatan laporan keuangan yang lebih sistematis, agar mudah dalam melakukan evaluasi kinerja. Hasil dari pengukuran kinerja keuangan selama tiga tahun terakhir, menghasilkan rata-rata ROI sebesar 7,17\%; rata-rata Net Profit Margin sebesar $14,91 \%$ dan rata-rata pertumbuhan pendapatan sebesar $11,46 \%$.

2. Berdasarkan hasil analisis data, sebanyak $75 \%$ pelanggan merasa puas terhadap produk yang dihasilkan. Produk yang dihasilkan dinilai mampu mereprentasikan kurikulum yang telah ditetapkan Departemen Pendidikan dan Kebudayaan. Dilain pihak, pelanggan masih mengeluhkan tentang pelayan pendistribusi produk. Produk yang sampai ketangan konsumen tidak pernah tepat waktu. Hal ini berpengaruh terhadap kemampuan perusahaan dalam mempertahankan pelanggan lama.

3. Keterlambatan pendistribusian produk disebabkan karena tidak efisiennya waktu yang digunakan untuk proses produksi. Tidak efisiennya ini disebabkan karena lamanya waktu yang dibutuhkan untuk proses pembuatan produk. Dalam membuat produk harus melewati beberapa tahapan proses, yang salah satu pengerjaannya harus ditangani pihak lain. Proses pengerjaannya bisa memerlukan waktu 2-3 hari. Faktor inilah yang menjadi salah satu penyebab terjadinya keterlambatan dalam pengiriman produk.

4. Masih rendahnya etos kerja karyawan CV. Amanah Surakarta disebabkan karena perusahaan kurang memperhatikan kepuasan karyawan. Karyawan merasa kurang puas terhadap peraturan yang diterapkan perusahaan. Peraturan itu dinilai lebih memberatkan karyawan, akibatnya berdampak pada hubungan kerjasama yang terjalin antara atasan dan bawahan. Selain itu kurangnya penghargaan dan pujian yang diberikan pimpinan kepada karyawan akan mempengaruhi semangat dan motivasi dalam bekerja yang nantinya akan menghambat produktivitas karyawan.

\section{Saran}

CV. Amanah Surakarta ada baiknya mencoba menerapkan Balanced Scorecard untuk menilai kinerja perusahaan. Pengukuran kinerja perusahaan dengan menggunakan Balanced Scorecard membantu perusahaan dalam mendeteksi apabila terjadi penurunan, sehingga lebih cepat dalam mengambil keputusan.

Namun demikian, sebelum menerapkan system Balanced Scorecard 
untuk mengukur kinerja perusahaan ada baiknya perusahaan memenuhi beberapa kriteria yang ada, diantaranya:

1. Memperbaiki Sistem pencatatan laporan keuangan dengan menggunakan seperangkat teknologi informasi (TI). Dengan sistem informasi yang berbasis komputer, dapat lebih mudah dalam menyampaikan informasi kepada seluruh karyawan dan mempermudah manajemen dalam mengambil keputusan-keputusan strategik.

2. Perusahaan lebih memperhatikan kepuasan pelanggan dalam hal pelayanan distribusi produk. Proses produksi dapat lebih efisien jika memiliki tenaga kerja yang ahli,kreatif, terampil, dan untuk mewujudkannya diperlukan training serta pelatihan terlebih dahulu.

3. Perusahaan juga harus memperhatikan kepuasan karyawan. Kepuasan karyawan sangat penting karena dapat memotivasi kinerja mereka yang nantinya dapat memperlancar proses produksi.

4. Mempersiapkan sumber daya manusia yang akan menjalankan sistem tersebut.

\section{DAFTAR PUSTAKA}

Tunggal, Amin Widjaja. 2001. Pengukuran Kinerja dengan Balanced Scorecard. Jakarta: Harvarindo.

Anthony, Robert dan Vijay Govindarajan. 1998. Management Control System. Edisi ke 9. Boston.

Kaplan, Robert S dan Norton, David P. 1991. Balanced Scorecard : Translating Strategy into Action, Boston : Harvard Business School Press.

Mulyadi. 2001. Balanced Scorecard Alat Manajemen Kontemporer uniuk Pelipat Ganda Kinerja Keuangan Perusahaan. Jakarta : Peneribit Salemba.

Mulyadi. 2007. Sistem Terpadu Pengelolaan Kinerja Personel Berbasis Balanced Scorecard. Yogyakarta : STIM YKPN. 
Jurnal Bisnis \& $M$ anajemen

Vol. 15, N 0. 1, 2015: 45 - 56 